\title{
Religiøsitet, identifikation og diskrimination - faktorer i en muslims hverdag i Danmark?
}

\author{
Af Azadeh Afsar
}

Det antages af studier i migrationslitteraturen, at folk, der migrerer fra en region i et land til en anden region, tilpasser deres religiøsitet til destinationsregionens (van Tubergen 2006: 4, Smith, Sikkink \& Bailey 1998: 494-506). Ud fra disse ideer må det antages, at immigranters religiøsitet har en tendens til at tilpasse sig modtagerlandets. I så fald kunne man forestille sig, at personer af muslimsk baggrund, der migrerer til Danmark qua tilpasningsprocesser med tiden vil blive mindre religiøse. Spørgsmålet er følgelig, om det danske samfund virker sekulariserende, eller om forholdene i Danmark netop synes at fremme religiøsiteten hos de, der føler, at religiøsiteten trues? Disse er nogle af de spørgsmål, der vil blive diskuteret i denne artikel.

Muslimske grupper og deres religiøsitet har udgjort et omdebatteret emne herhjemme, hvad enten det har været i medier, i de danske hjem, i det politiske felt eller på det danske arbejdsmarked. Emnets aktualitet har også betydet, at flere forskere har beskæftiget sig med emnet islam i Danmark. Fokus har her typisk været på en afmystificering af islam med teologiske og filosofiske beskrivelser af etik og ritualer (Simonsen 2006, Kühle 2006), på udvalgte muslimske grupper, eksempelvis studier af unge muslimer og deres religiøse oprør mod forældregenerationen (Johansen 2002) eller på dansk-muslimske konvertitter. Her kan nævnes antropolog Tina G. Jensen og religionsforsker Kate Østergaards forskningsprojekt, Omvendelse til islam i Danmark. Endelig er der sat fokus på udviklingen af euroislam, eksempelvis med afsæt i professor i islamologi, Tariq Ramadans teorier herom (Ramadan 2002: 183ff., Johansen 2002: 28-29). Der synes imidlertid ikke at foreligge forskning omkring migrationsrelaterede transformationer i muslimske immigranters religiøsitet, hvilket kan være med til at fastholde et unuanceret billede af gruppen af muslimske førstegenerationsimmigranter, der udgør en del af det danske samfund. Det er den manglende viden om et betydeligt relevant emne, der har igangsat mit speciale Migration og Religiøs Transformation - en sociologisk undersøgelse af førstegenerationsimmigranters religiøse identitet $i$ en dansk kontekst og nærværende artikel om specialets undersøgelsesresultater og konklusioner. Specialet er udarbejdet i samarbejde med Maj-Britt Madsen og afsluttet i marts 2007 ved Sociologistudiet ved Aalborg Universitet. 
Formålet med undersøgelsen har været at forklare og forstå, hvad der sker med muslimske førstegenerationsimmigranters religiøsitet i mødet med det danske samfund. Afgrænsningen til førstegenerationsimmigranter er foretaget ud fra et ønske om så vidt muligt at isolere mødet mellem to kulturer og den indflydelse, migrationen kan have på immigranternes religiøsitet. I forhold til andengenerationsimmigranter kan der argumenteres for, at man fra fødslen socialiseres med og influeres af den danske majoritet og deres forhold til religion. Til sammenligning er det ved førstegenerationsimmigranter muligt at se, hvorvidt en allerede etableret religiøs identitet (eller mangel herpå) udfordres og forandres i mødet med det danske samfund. Forandringer kan eksempelvis komme til udtryk som, at religiøsiteten kan tiltage, idet den kan blive en vigtig identitetsmarkør i forholdet til majoriteten, aftage som følge af tvivl, der kan opstå omkring det religiøse ståsted, eller inkorporeres i livet i det danske samfund. Forandringerne kan være afhængige af forskellige faktorer, som jeg her vil søge at belyse.

Undersøgelsen afgrænser sig til muslimske immigranter. Med benævnelsen muslim refererer her til en person, der betragter sig som muslim, eksempelvis fordi denne er født af muslimske forældre, har fået en muslimsk opdragelse, er vokset op blandt en muslimsk minoritet/majoritet etc. Det er følgelig agentens egen forståelse og kategorisering af sig selv, der er afgørende for min definition. I forbindelse med udvælgelsen af respondenter er der ikke stillet krav om, at de skulle være troende eller praktiserende muslimer, da tro og praksis netop kan have varieret som følge af migrationen til Danmark. Med religiøs identitet forstår jeg en kombination af:

- respondenternes religiøse selvopfattelse: hvor religiøs man betragter sig

- religionens indflydelse på deres liv: indflydelse på den måde man lever på til daglig, den måde man går klædt, synet på det danske samfund, synet på politiske spørgsmål, ægteskab og familieliv, samt

- det religiøse engagement: hvad gør man for at søge viden om religion (læse i hellige skrifter/andre bøger, pjecer og brochurer, lytte til religiøse ledere, diskutere religion med andre og se tv-programmer om religion), og hvor of- 
te kommer man i en religiøs forening, i en moske og/eller deltage i fredagsbønnen.

De tre dimensioner i den religiøse identitet måles i såvel oprindelseslandet som i Danmark. Disse tre dimensioner er på ingen måde udtømmende, ligesom de udvalgte parametre inden for de tre dimensioner ikke er udtømmende. De tre dimensioner er udvalgt på baggrund af - og følgelig afgrænset til - de spørgsmål, der er stillet i surveyundersøgelsen IntegrationsStatus 1. halvår 2004 foretaget af analysebureauet Catinét Research A/S. ${ }^{1}$ IntegrationsStatus ligger, sammen med ti kvalitative interviews, til grund for de empiriske resultater, jeg vil redegøre for i denne artikel. Den metodiske tilgang vil blive gennemgået senere.

Undersøgelsen angår førstegenerationsimmigranters religiøsitet $i$ mødet med det danske samfund. Det danske samfund har hidtil reageret tøvende og ad hoc på tilstedeværelsen af islam i Danmark:

Den danske model for, hvordan man forholder sig til islam, kan kort beskrives som manglende vilje generelt til at anerkende islam officielt ( $\mathrm{fx}$ gennem lovgivning), mens der ofte findes lokale ad hoc-løsninger på konkrete problemer. Den danske stat vægrer sig således ved at tildele islam og muslimer symbolske rettigheder og anerkendelser (Kühle 2006: 33f.).

Dette betyder dog ikke, at muslimer i Danmark lever under vanskeligere forhold her end andre steder, men blot at islam ikke fra officiel side modtager meget symbolsk støtte eller anerkendelse (ibid. 33f.). Dette synes også at fremgå af følgende eksempler: Islamudvalget, nedsat af landets biskopper med den hensigt at redegøre for folkekirkens forhold til mennesker af anden tro i Danmark, foretog i slutningen af år 2000 en undersøgelse, der indikerede, at folk indenfor folkekirkeligt regi gerne ser multireligiøsitet $\mathrm{i}$ de private hjem, men ikke i det offentlige rum: "Kravet om at assimilere sig i det offentlige rum er stærkt. Det stiller sig dog anderledes i privatsfæren. Der må man tro, tænke og gøre hvad man vil" (Nielsen 2000: 76). I overensstemmelse hermed skrev den danske statsminister, Anders Fogh Rasmussen, i en artikel i Politiken (3. sektion side 6), den 20. maj 2006, at: "For at sikre en fortsat stærk sammenhængskraft i fremtiden er det derfor efter min opfattelse ønskeligt, at religion kommer til at fylde mindre i det offentlige rum”. Sættes fokus 
på den danske befolkning generelt, fremgår det af Værdiundersøgelsen fra 1999, at 77 \% finder, at samfundet er bedst tjent med, at indvandrere ikke fastholder deres skikke og traditioner men i stedet overtager de traditioner, der er i Danmark (Nielsen 2004: 300). Når fokus sættes på, hvad der sker med immigranters religiøsitet i mødet med det danske samfund, skal det forstås ud fra antagelsen om, at mødet kan udgøre et skæringspunkt mellem tilværelsen som majoritetsgruppe i et muslimsk land og minoritetsgruppe i det danske samfund. Hvor den religiøse praksis i oprindelseslandene typisk udgør en del af såvel det private som det offentlige rum, og religion sædvanligvis er bevaret som det, der er med til at regulere det sociale liv, kan religiøsiteten i Danmark i højere grad karakteriseres som individualiseret og privatiseret. Forholdet mellem den sekulære majoritet og de muslimske minoriteter kan i bedste fald bestå i gensidig anerkendelse, hvilket kan være til nytte for en gnidningsfri integration. Men forholdet kan også bestå i manglende empati og forståelse for hinanden.

Spørgsmålet omkring transformationer i den religiøse identitet i mødet med det danske samfund er søgt belyst qua en metodekombination bestående af en kvantitativ surveyundersøgelse og 10 kvalitative interviews med førstegenerationsimmigranter fra muslimske lande. Den kvantitative del af metodetrianguleringen består, som allerede beskrevet, af IntegrationsStatus 1. halvår 2004. Respondenterne, 818 i alt, er flygtninge og indvandrere (i denne artikel anvendes fællesbetegnelsen immigranter) fra Pakistan, Tyrkiet, Somalia, Ex. Jugoslavien, Iran, Irak og Libanon, Palæstina/statsløse. IntegrationsStatus anvendes i kombination med kvalitative interviews med respondenter fra henholdsvis Iran, Tyrkiet og Libanon. Mit formål med anvendelsen af IntegrationsStatus har været at belyse immigranternes religiøsitet i Danmark, idet der i IntegrationsStatus ikke indgår spørgsmål om religiøsiteten i oprindelseslandet. Som supplement kan de kvalitative interviews belyse religiøsiteten i oprindelseslandet såvel som her. Respondenterne fra de kvalitative interviews er udvalgt skønsmæssigt på baggrund af analysen af de kvantitative data, der - som det vil blive redegjort for senere - indikerer, at der er en sammenhæng mellem nationalitet og religiøsitet, således at immigranter fra Iran kan karakteriseres som de mindst religiøse, mens immigranter fra arabisktalende lande kan karakteriseres som de mest religiøse. Immigranter fra Tyrkiet placerer sig midt imellem og kan følgelig karakte- 
riseres som mellemreligiøse. Ved udvælgelsen af respondenter er der blandt andet tilstræbt en ligelig kønsfordeling, respondenter fra forskellige aldersgrupper, bosat i forskellige geografiske dele af Danmark i såvel etniske enklaver som i områder med et flertal af danske naboer. Den endelige udvælgelse af respondenter, der opfyldte ovenstående krav, har været baseret på to grundlæggende kriterier: Det første, at respondenten kunne gøre sig forståelig på enten dansk, engelsk eller farsi - det andet kriterium har været, at respondenten har været bosat $\mathrm{i}$ oprindelseslandet som minimum op til teenagealderen. Den konkrete tilgang til opsøgning af interviewpersoner har været, at interviewpersonen ikke måtte indgå i egne bekendtskabskredse, men at disse kredse kunne udgøre et udgangspunkt. Hensigten har været at komme ud i tredje led for derved at distancere sig fra at benytte respondenter fra samme omgangskreds. Der er eksempelvis taget kontakt til person $\mathrm{A}$, som har henvist til $\mathrm{B}$, der har henvist til $\mathrm{C}$, som er blevet interviewet. $\mathrm{C}$ har dernæst henvist til D, som har henvist til E, der henviser til person F, som interviewes.

Opsamlende søger denne artikel at belyse, hvad der sker med muslimske førstegenerationsimmigranters religiøsitet i mødet med det danske samfund. Fokus er således på ændringer i den religiøse selvopfattelse, religionens indflydelse samt det religiøse engagement. Disse ændringer kan være igangsat i forbindelse med overgangen fra at udgøre en majoritet $i$ et samfund, hvor religion har en vigtig rolle $i$ det offentlige rum til at udgøre en minoritet i det danske samfund, hvor religion i højere grad end i oprindelseslandet er henvist til det private. I de følgende afsnit vil der blive redegjort for religiøsiteten i Danmark, set i relation til religiøsiteten i oprindelseslandet. Denne redegørelse vil blive efterfulgt af en diskussion af hvilke faktorer, der synes at have indvirkning på transformationer i den religiøse identitet, herunder:

- hvilke faktorer knyttet til det danske samfund, der kan have indvirkning på ændringer i den religiøse identitet, eksempelvis identifikation med danskere, oplevelsen af diskrimination, og den etniske konstellation af vennekredsen samt det nære boligområde, og

- hvilke faktorer knyttet til oprindelseslandet, der kan tænkes at have indflydelse, her til eksempel den religiøse retning (sunni/shia eller islam i øvrigt) eller årsag til migration (flygtning eller indvandrer). 


\section{"Jeg er en helt almindelig muslim" - indblik i den religiøse selvopfattelse}

Respondenternes religiøse identitet er i IntegrationsStatus blandt andet målt med en variabel omkring hvor religiøs, man betragter sig. En frekvensanalyse angiver, at $36 \%$ af respondenterne betragter sig som værende slet ikke/mindst mulig religiøse, $34 \%$ betragter sig som mellemreligiøse, mens $26 \%$ betragter sig som mest mulig religiøse. En frekvensanalyse af respondentens vurdering af religiøsitetens udvikling i de forgangne fem år viser, at religiøsiteten er steget for $18 \%$ af respondenterne, har været uforandret for majoriteten, svarende til $68 \%$, og er faldet for $11 \%$. Et flertal af respondenterne fra IntegrationsStatus betragter sig således som mellem- eller mest mulig religiøse. For de flestes vedkommende har den religiøse identitet været konstant de sidste fem år, mens der er stærke indikatorer på, at de, der nu betragter sig som mindst mulig religiøse med tiden har haft en aftagende religiøsitet, mens de, der nu betragter sig som mest mulig religiøse har haft en tiltagende religiøsitet i de forgangne fem år. Det at betragte sig som mellemreligiøs eller mest mulig religiøs synes imidlertid ikke nødvendigvis at indebære, at religion har indflydelse på den måde, man lever sit liv, at man gør noget for at søge viden om sin religion, eller at man deltager i religiøse samlinger. Se tabel 1: 
Tabel 1. Hvor religiøs vil du sige, at du selv er?

\begin{tabular}{|c|c|c|c|}
\hline & \multicolumn{3}{|c|}{ Hvor religiøs vil du sige, at du selv er? } \\
\hline & Mindst mulig religiøs & Mellemreligiøs & Mest mulig religiøs \\
\hline Religion har ingen/lille indflydelse & $85 \%$ & $64 \%$ & $59 \%$ \\
\hline Religion har nogen indflydelse & $11 \%$ & $26 \%$ & $23 \%$ \\
\hline Religion har stor indflydelse & $5 \%$ & $11 \%$ & $18 \%$ \\
\hline $\begin{array}{l}\text { Gør intet/meget lidt for at få viden om min reli- } \\
\text { gion }\end{array}$ & $66 \%$ & $41 \%$ & $2 \%$ \\
\hline Gør noget for at få viden om min religion & $33 \%$ & $54 \%$ & $5 \%$ \\
\hline Gør meget for at få viden om min religion & $2 \%$ & $5 \%$ & $13 \%$ \\
\hline Kommer regelmæssigt i en religiøs forening & $7 \%$ & $10 \%$ & $18 \%$ \\
\hline $\begin{array}{l}\text { Kommer ikke regelmæssigt i en religiøs for- } \\
\text { ening }\end{array}$ & $93 \%$ & $90 \%$ & $82 \%$ \\
\hline Kommer regelmæssigt i en moske & $14 \%$ & $31 \%$ & $45 \%$ \\
\hline Kommer ikke regelmæssigt i en moske & $86 \%$ & $69 \%$ & $55 \%$ \\
\hline Deltager jævnligt i fredagsbønnen & $10 \%$ & $28 \%$ & $42 \%$ \\
\hline Deltager ikke jævnligt i fredagsbønnen & $90 \%$ & $72 \%$ & $58 \%$ \\
\hline
\end{tabular}

Af de kvalitative interviews fremgår det, at identiteten som religiøs muslim ikke betragtes som ønskværdig. De, der betragter sig som religiøse, forholder sig meget defensivt i beskrivelsen af deres religiøsitet: ”Jeg var ikke fanatisk. (...) Jeg vil gerne være en åben og moderat, god muslim”. På samme vis bruges ofte betegnelser som ”jeg er ikke ret religiøs" eller "jeg er en helt almindelig muslim”. Dette kan læses som, at den nominelle identitet, forstået som betegnelsen/labellen som 'religiøs muslim', ikke betragtes som ønskværdig, idet den af respondenterne selv forbindes med fundamentalisme, ensporethed etc. (Jenkins 2006:47). Den nominelle identitet søges modificeret qua den defensive tilgang, således at respondenten føler, at denne giver et mere reelt billede af sig selv. Respondenternes sidestilling af en religiøs identitet med en fundamentalistisk, muslimsk identitet kan forklares med, at det ydre moment i form af andre mennesker spiller en afgørende rolle i den individuelle identifikationsdialektik. Det skyldes, at andre mennesker, i form af deres reaktioner over for os og deres behandling af os, for eksempel ved kategorisering, er med til at skabe vores identitet (ibid: 98f.). Vores selvidentifikation afhænger således af vores kumulative oplevelser med andre mennesker, hvorved andre menneskers kategorisering af os internaliseres til at blive vores egen kategorisering af os selv. Vores 
efterfølgende adfærd og biografi organiseres da med henvisning til en identifikation, som nu ikke alene er en ydre identifikation, men også en indre selvidentifikation (ibid: 100). Den ydre identifikation som fundamentalistisk muslim, eksempelvis oplevet i medier eller på politisk niveau som følge af angrebet på World Trade Center 11. september 2001 eller den danske Muhammedkrise, er så at sige blevet til en indre selvidentifikation, som respondenterne kæmper imod ved automatisk at træde i en defensiv position.

\section{Kontekstrelateret transformation i religiøs selvopfattelse}

Blandt respondenterne fra de kvalitative interviews er der nogle, der med migrationen til Danmark er blevet mindre religiøse som resultat af et kritisk blik på deres religiøsitet, og den dag i dag betragter sig som ikke religiøse eller meget lidt religiøse.

Da jeg boede i England, var jeg ikke så kritisk, som jeg er nu, og jeg troede lidt blindt på gud og var lidt religiøs. (...) Hvis man spurgte mig i England, hvilken religion jeg bekendte mig til, ville jeg sige islam. Men efter jeg kom til Danmark og blev mere oplyst ved at se de her tv-programmer og læse flere bøger, så ændrede jeg mig $100 \%$ og kunne se, at jeg før var faret vild (Amir, iransk mand, 58 år).

I Danmark jeg tænker på lidt religion, så tænker jeg, at jeg skulle tage mig sammen og udvikle mig. (...) Man bliver nødt til at udvikle sig selv. Jeg venter ikke på, at Allah hjælper mig. Det hjælper ikke. Det har jeg fundet ud af. Derfor, min religiøsitet er blevet mindre. Nu tror jeg mere på mig selv. (...) Jeg tror på Allah, men jeg begynder at tro på mig selv meget mere (Elmas, tyrkisk kvinde, 43 år).

De nævnte respondenter er eksempler på personer, der med migrationen til Danmark er blevet mindre religiøse som resultat af et kritisk blik på deres religiøsitet. Det er således ikke længere i samme grad religion men noget andet (uddannelse eller eksempelvis den nationale baggrund), der har indflydelse på, hvordan respondenten opfatter og former sin sociale virkelighed. Under den primære socialisering er ovennævnte respondenter blevet influeret af nærtstående personer, såkaldte signifikante andre, typisk forældre (Berger 1969:4ff., Berger \& Luckmann 2004:169ff.). Begge de nævnte respondenter har haft troende og praktiserende forældre, der imidlertid ikke - ifølge respondenterne - har søgt at videregive den religiøse tradition til dem. Dette er imidlertid (hvis ikke det allerede er sket under den primære socialisering) sket gennem den sekundære socialisering, hvor respon- 
denterne har haft obligatorisk koranundervisning og undervisning i "islamisk opførsel” i skolen. Da der under den sekundære socialisering ikke er samme emotionelle relation til de signifikante andre, som der er ved primær socialisering (forældre vs. skolelærer), bliver den virkelighed, der internaliseres gennem den sekundære socialisering gerne mere skrøbelig end viden fra den primære socialisering. Det betyder, at den virkelighed, der omfatter religion, er stærkere blandt de, hvor religion har spillet en stor rolle i den primære socialisering. Dette vil kunne forklare, hvordan religiøs tro og praksis kan have en mindre betydning blandt respondenter, der i forvejen ikke har fået denne internaliseret.

Blandt respondenterne fra de kvalitative interviews forekommer imidlertid også eksempler på respondenter, der med migrationen til Danmark midlertidigt mister interessen for deres religion, idet de assimileres i det nye samfund. Religiøsiteten genopstår dog og styrkes i visse tilfælde efter en periode.

Fordi når man kommer, så ser man et helt nyt samfund og så med helt masse... Og jeg var kun sammen med danskere, ikke? (...)Og så glemmer man det jo [sin tro]. Og så siger man; hold da op! Det er jo paradis! Og så går man på diskotek, og så kommer man til at drikke sig fuld, ikke? (...) I en periode, der tænkte jeg ikke så meget på det. (...) Jeg havde dårlig samvittighed, men alligevel jeg blev ved. (...) Jeg forsatte med det i flere år, indtil jeg blev sådan mere moden, som jeg sagde, og så kom jeg til at tænke på; for fanden, nu må du altså holde op. Det kan ikke gå på denne måde (Ali, iransk mand, 33 år).

I mødet med personer, der ikke deler samme virkelighedsopfattelse, synes det vanskeligt at opretholde det oprindelige symbolske univers. Forudsætningen for at kunne opretholde dette symbolske univers er, at den skal give mening. En struktur, der giver mening og bidrager til at bibeholde den subjektive virkelighedsopfattelse kaldes for en plausibilitetsstruktur (Berger \& Luckmann 2004:169ff.). Ved migrationen til Danmark synes Alis plausibilitetsstruktur at blive forstyrret og midlertidig brudt, således at det eksempelvis ikke længere giver mening at være religiøs og føre den beskrevne livsstil. Følgelig kan individet skifte virkelighedsopfattelse, hvorved det gennemgår en ny socialiseringsproces. De nye signifikante andre har i det konkrete eksempel med Ali udelukkende bestået af personer med dansk baggrund, og det har følgelig været deres normer og værdier, som Ali har internaliseret gennem socialiseringen. For at den nye verden skal forekomme sammenhængende, må andre "modstridende" verdener fortrænges, deriblandt den verden, som 
respondenten levede i før. Dette kan forklare, hvorfor Ali "glemmer" religionen i mødet med det nye, danske samfund. At man glemmer religionen hænger følgelig sammen med en udskiftning af de signifikante andre, der har fundet sted med interaktionen med personer af dansk baggrund. Den ændrede virkelighedsopfattelse synes dog at være skrøbelig. Ved mødet med nye signifikante andre - en referencegruppe, der deler samme virkelighedsopfattelse som den, man oprindeligt havde - synes erindringen herom at vækkes til live. Dette møde synes netop at være den faktor, der udløser minderne om det, der før gav mening. For Ali gør det sig således gældende, at han blev opmærksom på sin baggrund og dermed sin religion, da han flyttede på et kollegium, hvor der boede mange personer af samme nationale og religiøse baggrund som han selv: "Og det var også der, hvor det begyndte. Hvor jeg begyndte at tænke sådan lidt mere på min kultur og på de iranske traditioner, og hvad jeg lavede i fortiden og om min religion og alt det der."

\section{Religionens indflydelse på den måde, man lever sit liv}

Begrebet indflydelse skal her forstås som den magt, individet kan tillægge sin religion, således at den bliver bestemmende for, hvordan man skal tænke eller handle i livet. Overordnet synes religion ikke at have den store indflydelse på respondenternes liv. Således mener $72 \%$ af respondenterne fra IntegrationsStatus, at religion har ingen/lille indflydelse, $18 \%$ mener, at den har nogen indflydelse, mens kun $9 \%$ mener, at religion har stor indflydelse. At religion har ingen/lille indflydelse på, hvordan man lever sit liv, betyder typisk, at religion ikke har indflydelse på den måde, man går klædt, synet på det danske samfund eller politiske spørgsmål og på ægteskab og familieliv. Der hvor religion synes at have størst indvirkning er i forhold til den måde, respondenterne lever på til daglig og dermed på spise-/drikkevaner, børneopdragelse, renlighed og fysisk og etisk omgang med andre $\mathrm{mm}$.

Som diskuteret i det foregående afsnit om den forandrede religiøse selvopfattelse i Danmark, kan forklaringen være en ændring i plausibilitetsstrukturen, således at omgang med nye signifikante andre, nærmere bestemt en dansk bekendtskabskreds, kan medføre internalisering af deres verdensopfattelse. Dette kan som allerede nævnt forklare Alis ændring i drikkevaner. En anden forklaring kan være, at spise- og drikkevaner samt beklædning er nogle "ydre" aspekter af religiøsiteten - set i modsætning til tro, der kan karakteriseres 
som et "indre" aspekt. De ydre aspekter kan da ændres eller så vidt mulig tilpasses den nye kontekst af forskellige årsager, eksempelvis 1) for at undgå stempling, fordi man skiller sig ud, sådan som tilfældet er for enkelte af respondenterne fra de kvalitative interviews i forhold til det at bære det muslimske tørklæde, eller 2) fordi det ganske enkelt er nemmere at tilpasse sig, idet livet i Danmark kan betyde, at alkohol er på supermarkedshylden, mens halalslagtet kød ikke er. I forlængelse heraf er det interessant, at den svækkede indflydelse, som religion har på disse ydre aspekter i Danmark, kan opvejes af en styrket tro, altså et indre aspekt. Således fortæller Soussan:

Det kan godt være, at jeg i det ydre har ændret mig, siden jeg var i Iran. Jeg er ikke lige så påpasselig med min hidjab her som tidligere. Når jeg går ud og spiser, tænker jeg mindre over, om det er halalslagtet kød, jeg spiser. Men jeg har fået en dybere tro (Soussan, iransk kvinde, 65 år).

\section{Det religiøse engagement}

Betragtes aktivitetsniveauet i Danmark, fremgår det af IntegrationsStatus, at $53 \%$ af respondenterne gør intet eller meget lidt for at søge viden om deres religion. Det betyder typisk, at man hverken læser hellige skrifter eller andre bøger om religion, ikke lytter til religiøse ledere, ikke diskuterer religion med andre, ligesom man heller ikke ser tvprogrammer om religion. De, der ifølge vidensindekset gør meget lidt for at søge viden, kommer dog jævnligt i moskeen eller deltager i fredagsbønnen. En mellemgruppe svarende til $41 \%$ gør "noget". Kun $5 \%$ af alle respondenterne betragter sig som meget engagerede. At være meget engageret betyder typisk, at man gør samtlige nævnte ting. Respondenterne deler sig således i to lejre med et lille flertal af de, der viser "intet/meget lille" engagement og de, der gør "noget" eller "meget". De fem mest foretrukne aktiviteter synes at være at læse hellige skrifter (29\%), komme regelmæssigt i en moske (26\%), deltage jævnligt i fredagsbønnen eller se tv-programmer om religion (23\%), læse andre bøger om religion (21\%), og endelig at diskutere religion med andre (20\%).

De kvalitative interviews nuancerer imidlertid data fra IntegrationsStatus med en tilføjelse af aktiviteter $\mathrm{i}$ forbindelse med at søge viden om sin religion. Dette gælder Korangrupper, hvor en gruppe kvinder mødes for at fortolke og diskutere dele af Koranen, jf. følgende udsagn af Elmas:” ... nogle gange kvinder samlede sig og gav fatwa: sad og 
fortalte om nogle kapitler i Koranen. Fortæller fx om familieliv, kulturliv, hvordan vi holder os rene, hvordan vi bliver gode muslimer, hvad sagde profeten Muhammed, osv."

Blandt respondenterne fra de kvalitative interviews forekommer interessante eksempler på, at man under opholdet i Danmark begynder at søge viden om sin religion. Dette kan i min optik være udtryk for en søgen på mening, der kan findes i religion, men ikke nødvendigvis er at finde der. Amir fortæller:

Så begyndte jeg at søge efter en række bøger, som er forbudt i Iran, men som jeg kunne få fat $\mathrm{i}$ her. Dem læste jeg så, og de har oplyst mig mere. Jeg er meget mere glad nu, hvor jeg ikke tror, end jeg var, da jeg var troende. Jeg har ikke brug for troen. Jeg har et godt liv...

Forklaringen på det stigende engagement kan være, at man under opholdet i Danmark oplever, at identiteten udfordres som følge af en udskiftning af de signifikante andre. Dette kan forklares med, at man kan føle en forskellighed fra den danske befolkning, der kan bestå i danskeres normer og værdier, eksempelvis i forhold til alkohol, skilsmisse etc., der i nogle tilfælde kan betragtes som tegn på moralens opløsning. Hermed kan egne moralregler - gerne med rødder i religion - aktualiseres og nødvendiggøres (Riis 2005: 21f.). Immigranten kan således i de nye utrygge omgivelser søge tryghed i noget, der er kendt, hvilket kan være ensbetydende med en forstærket markering af religion. Tilstedeværelsen i Danmark kan således medføre en styrket bevidsthed om identitet og værdigrundlag og en refleksion over ens traditionelle værdier og hvilke af disse, der er værd at fastholde.

Ligeledes forekommer der i de kvalitative interviews eksempler på, at det religiøse engagement kan svækkes under opholdet i Danmark enten på grund af en manglende interesse, manglende mulighed, midlertidigt fordi man er optaget af andet eller noget helt fjerde. Soussan begrunder det svækkede engagement med manglende muligheder herfor i Danmark: "Det er meget lettere der [Iran]. (...) Jeg har bedre muligheder for at praktisere min tro der. Her kan jeg ikke gøre noget. Men indeni har jeg bevaret min tro her.” 


\section{Faktorer af betydning for den andrede religiøsitet}

IntegrationsStatus viser som ovenfor beskrevet, at flertallet af respondenterne karakteriserer sig som mellemreligiøse med en uforandret religiøsitet inden for de sidste fem år. Det gør sig gældende for denne gruppe, at religion har ingen/lille indflydelse på deres liv, ligesom det religiøse engagement er sparsomt. Den religiøse selvopfattelse, religionens indflydelse samt det religiøse engagement synes at være kontekstafhængig, således at religiøsiteten typisk ændrer sig i mødet med det danske samfund, enten ved en midlertidig intensivering eller et midlertidigt fald. Ændringen kan imidlertid også have en mere varig karakter, således at den for nogles vedkommende erstattes af noget andet, mens den for andres vedkommende intensiveres, typisk fordi den føles truet.

I det følgende vil jeg redegøre for en række faktorer knyttet til destinationslandet, som kan have indflydelse på immigranternes religiøsitet. Her vil jeg komme ind på immigranternes forhold til den danske majoritet, herunder identifikation med danskere og oplevelsen af diskrimination. Også faktorer som den etniske konstellation af beboere i boligområdet og den nære vennekreds vil blive diskuteret i forhold til religiøsiteten. Dette afsnit vil blive fulgt op af et afsnit om faktorer knyttet til oprindelseslandet, som synes at have indvirkning på immigranternes religiøsitet i det danske samfund.

\section{Forholdet til den danske majoritet set $i$ relation til religiøsiteten}

I forbindelse med forholdet til den danske majoritet fremkommer to interessante resultater. Det ene drejer sig om den signifikante korrelation, der viser sig mellem religiøsitet og det at betragte sig som dansker. Det andet i forbindelse med korrelationen mellem religiøsitet og diskrimination. En frekvensanalyse af hvor dansk respondenterne føler sig viser, at den største gruppe svarende til $58 \%$ slet ikke eller meget lidt føler sig dansk, mens 28 $\%$ placerer sig i midten, og kun $13 \%$ føler sig rimelig meget/fuldt ud som en dansker. En korrelationsanalyse af forholdet mellem danskhed og religiøsitet indikerer, at der er en svag men signifikant sammenhæng mellem, hvor religiøs man betragter sig, og hvor dansk man føler sig, således at det at være dansk og det at være religiøs synes at udelukke hinanden. ${ }^{2}$ Jo mere religiøs man betragter sig, desto mindre dansk føler man sig. Tendensen går igen: Jo mere dansk man betragter sig, desto større er sandsynligheden for, at religiøsiteten har været faldende inden for de sidste 5 år. $^{3}$ Ligeledes er der en tendens til, 
at jo mere dansk man betragter sig, desto mere sandsynligt er det, at religion ikke har indflydelse på særlig mange aspekter i livet. ${ }^{4}$ Resultaterne indikerer, at der hos respondenterne forekommer en forestilling om en modsætning mellem danskhed og religiøsitet. En forklaring herpå kan være, at en sådan modsætning kommer til udtryk hos den danske majoritet og signaleres fra politisk niveau og i medier, og som konsekvens heraf internaliseres af de muslimske minoriteter. Hvis signalet er, at man som dansker ikke er religiøs, må det betyde, at man som troende og praktiserende muslim ikke kan karakterisere sig som dansker. Dette kan netop være en af de problematikker, som flere andengenerationsimmigranter tager fat $\mathrm{i}, \mathrm{i}$ et forsøg på at påvise, at man godt kan være dansk og muslim på en og samme tid.

En anden interessant korrelation fremkommer som beskrevet $\mathrm{i}$ forbindelse med følelsen af diskrimination. Det synes oplagt, at man i et land som Danmark, hvor religion er henvist til det private rum, vil betragte sig som genstand for xenofobi fra majoritetsgruppen, jo mere religiøs man er. Man kunne således forvente, at oplevelsen af diskrimination vil øges, jo mere religiøs man betragter sig. Af IntegrationsStatus fremgår imidlertid, at flertallet af respondenterne, svarende til $63 \%$, ikke føler sig diskrimineret, mens det mindretal, der føler sig diskrimineret, typisk er de mindre religiøse. Følelsen af diskrimination falder, jo mere religiøs man betragter sig, hvilket er overraskende. Det er således primært de meget lidt religiøse, der føler sig udsat for diskrimination. Forklaringen kan hentes i de kvalitative interviews. Her forekommer enkelte eksempler på, at den danske majoritet tilskriver immigranterne en traditionsbestemt religiøs identitet uanset den enkeltes personlige livsanskuelse. Hermed fungerer religion som et stigma, der markerer immigrantens status i samfundet (Riis 1996: 100ff.). Som eksempel kan nævnes Ibrahim, der fortæller:

Jamen, det er sådan: Når du for eksempel stiller mig et spørgsmål, så går du ud fra, at jeg er meget religiøs. Det oplever man også, når man kommer til sin arbejdsplads eller til et møde eller en konference (...)med spisning og snak, og når man skal have gaver. Så siger de: Du er jo muslim. Du må ikke få to flasker vin. Og så står man der og siger: Hvem fanden har fortalt dig det? Pr. automatik så er de andres afgørelse den rigtige, og man bliver placeret et bestemt sted. (Ibrahim, tyrkisk mand, 50 år). 
Af IntegrationsStatus fremgår, at de, der betragter sig som meget lidt religiøse, har en tendens til at føle sig udsat for diskrimination på såvel arbejdspladsen, uddannelsesstedet, ved job- og boligsøgning, på offentlige kontorer, i offentlig transport, ved indkøb, i boligkvarteret, i medier og hos politikere, i sports og fritidsklubber, i nattelivet etc.

\section{Diskrimination af de mellem/mest mulig religiøse}

Mellem $19 \%$ - $23 \%$ af de, der betragter sig som mellem/mest religiøse, føler sig diskrimineret i Danmark. For at få et indblik i hvordan og hvor diskriminationen opleves, er der kigget i de kvalitative interviews. Følelsen af diskrimination blandt de mere religiøse synes at hænge sammen med en følelse af ikke at kunne praktisere sin religion som ønsket, fordi denne praksis opleves som problematisk og som genstand for diskrimination i det danske samfund. Således fortæller Abdul-Karim:

Jeg er godt integreret, men jeg vil helst ikke være integreret, fordi uanset hvad man gør, så er man ikke accepteret. Så det er lige meget. Den eneste måde at blive accepteret på, det er med at skille sig af med sin religion. Så bliver du bedre accepteret. Og et stort eksempel er Naser Khader, ikke? Det er... han er stadig lidt ikke accepteret, af mange politikere, vil jeg sige på den måde. Men i det danske samfund, der er han meget accepteret, fordi han tager islam skjorte af, og så bliver han accepteret. (...) Så længe jeg praktiserer islam, så længe er jeg ikke accepteret (Abdul-Karim, libanesisk mand, 34 år).

Abdul-Karim fortæller endvidere om mediernes fokus på muslimer i Danmark: "Der kommer noget næsten en gang om ugen, der får en til at kaste op. Og alt det der, der kommer i fjernsynet, ikke også? Man gider slet ikke. Nogen gange, man gider slet ikke være her”. Ovenstående indikerer, at religiøsitet synes at medføre en følelse af at blive diskrimineret i medier. Diskriminationen opleves dog også fra politisk side. Jo mere indflydelse religion har i ens liv, desto større tendens er der til, at man føler sig diskrimineret af politikere. ${ }^{5}$ Det samme gør sig gældende i forhold til at søge viden om sin religion. ${ }^{6}$ Kausaliteten kan imidlertid lige så vel tænkes omvendt. Således kan diskrimination muligvis medføre øget religiøsitet. I så fald ville der være tale om, at mediers og politikeres fremstilling og kategorisering af muslimer føles diskriminerende, hvilket kan medføre, at den religiøse identitet føles truet. Som konsekvens heraf kan immigranten finde det nødvendigt at beskytte sin religiøsitet, hvorved religiøsiteten styrkes. I de kvalitative interviews forekommer Abdul-Karim som et godt eksempel herpå. Efter 11. september 2001 
har han som følge af den negative fokus på islam blandt andet i medier og hos politikere anlagt skæg for tydeligere at signalere, at han er muslim: "Jeg vil ikke skjule min identitet, for at gøre dig tilfreds ...” Abdul-Karim understreger presset på muslimer i Danmark yderligere:

Jeg vil sige, efter at Dansk Folkeparti har været en del af regeringen, så har vi, religiøs og ikke religiøs, tabt meget. Og det bliver værre og værre. (...) Og det vigtigste at vi som muslimer, som mindretal, vi bliver ikke hørt efter. Vi bliver bare mast simpelthen. Så i en by ligesom Aarhus, vi er jo... jeg ved ikke, om vi er 20.000 eller 30.000. Jeg tror, at det er 20.000 muslimer. Vi kan ikke engang få lov til at bygge en moske og på den måde, så føler man sig meget... og sådan nogle buddhister, de har deres eget tempel, ikke også? Og det er kun... de er ikke en gang, jeg ved ikke, om det er 500 eller 1.000 buddhister i Aarhus, og så har de deres eget tempel, ikke også? De bygger deres eget. Vi får ikke lov til noget som helst på den måde og... (...) Jeg vil ikke bo $i$ et land, som ikke respekterer mig selv som person.

Resultaterne synes at indikere, at hvad der sker med førstegenerationsimmigranters religiøsitet i mødet med det danske samfund, afhænger af, hvor meget man identificerer sig med danskere og om man føler sig diskrimineret. Føler man sig diskrimineret, kan religiøsiteten muligvis styrkes som et værn mod, at man er udsat. Er det ikke muligt at identificere sig med den danske majoritet, kan det være mere nærliggende at bevare de oprindelige traditioner og værdier, herunder de religiøse.

\section{De noere omgivelsers indvirkning på religiøs identitet}

En anden faktor i forbindelse med destinationslandet er de nære omgivelsers indvirkning på den religiøse identitet, herunder boligområdet og vennekredsen. Her kan man se på, om koncentrationen af immigranter i boligområdet og vennekredsen kan have betydning for religiøsiteten, og i så fald, hvordan? Af IntegrationsStatus fremgår, at $59 \%$ af respondenterne er bosat i områder med kun/overvejende beboere af dansk baggrund, mens 24 \% bor i områder med ligelig fordeling og 15 \% i et boligområde med overvejende/kun beboere af udenlandsk baggrund. I forhold til vennekredsens etniske konstellation fremgår det, at $43 \%$ af respondenterne har en blandet vennekreds. Der er derimod flere personer med en vennekreds bestående af et flertal af udenlandsk baggrund (38 \%), end der er personer med en vennekreds primært bestående af personer af dansk baggrund (16 \%). 
Den etniske beboersammensætning og vennekredsen synes at have indvirkning på mange aspekter af religiøsiteten. Jo flere personer af anden etnisk baggrund end dansk man omgås - såvel i den nære vennekreds som i boligområdet - desto mere sandsynligt synes det at være, at man betragter sig som mere religiøs, udviser et højere religiøst engagement, er blevet mere religiøs i de forgangne fem år, og at religionen har mere indflydelse på den måde, man lever sit liv. Forklaringen herpå kan delvis være en indefra kommende bevidsthed omkring den religiøse identitet, der styrkes i nærhed af signifikante andre, der deler samme verdensopfattelse som en selv, hvorfor man også søger mere viden om, hvad denne religion, som man vier sig til, indebærer af værdier og leveregler. Der kan imidlertid tillige være tale om en udefra kommende bevidstgørelse af det religiøse ophav i form af ros for "korrekt" muslimsk adfærd eller sladder i forbindelse med uacceptabel adfærd, ergo en social kontrol. En mere plausibel forklaring kan imidlertid være, at valget af vennekreds kan være baseret på ens religiøsitet som hos Soussan: "... jeg [har] brugt 60 år af mit liv på at udvælge de mennesker, jeg omgås. Alle omkring mig er gode, troende mennesker. Alle lever et rent liv" og Abdul-Karim: "Selvfølgelig de er arabere, fordi jeg vil ikke befinde mig et sted, hvor der bliver drukket og holdt fest og sådan noget”, og siger om sin muslimske vennekreds: "Religion, det er vores liv. Så man taler om religion ved en hver bevægelse". I forhold til boligområdet synes der i de kvalitative interviews at være indikatorer på, at respondenten netop vælger at bosætte sig i enklaven, fordi dette gør tilværelsen som muslim i Danmark lettere, jf. følgende citat af Abdul-Karim:

\footnotetext{
Bor man på landet, har man ikke muslimske venner eller kontakt til kulturcentre og islamiske foreninger (...), og er man i forvejen ikke religiøs, så tror jeg, at man aldrig bliver religiøs. Selvfølgelig, det er samfundet, naboerne, det smitter. Så jeg tror, at mange af dem, der for eksempel bor i Gellerupparken, de bliver religiøse på grund af, at der er en god kontakt til islam. Ikke også? Der er gode forhold. At hvis nu en pige godt vil gå med tørklæde og ser, at hundrede andre går med tørklæde, så vil hun også turde gå med tørklæde.
}

Der synes følgelig i de kvalitative interviews at være eksempler på oplevede problematikker i forbindelse med at være praktiserende muslim og bo i et boligområde med et flertal af beboere af dansk baggrund. Som eksempel kan nævnes Soussan, der føler, at hun bliver betragtet som et tilbagestående menneske blandt andet $\mathrm{i}$ forbindelse med, at hun bærer tørklæde. Den etniske enklave og den overvejende udenlandske vennekreds kan 
således ses som en ønskværdig ramme, hvori man kan praktisere sin religion uden diskrimination fra sine omgivelser.

\section{Faktorer knyttet til oprindelseslandet}

Som tidligere beskrevet kan andre faktorer knyttet til oprindelseslandet tillige tænkes at have indvirkning på respondenternes religiøsitet i Danmark. Sådanne faktorer kunne tænkes at være oprindelsesland overordnet, den religiøse retning nærmere betegnet om respondenten er shiamuslim, sunnimuslim eller muslim af anden retning, og endelig om respondenten er rejst fra oprindelseslandet som flygtning eller indvandrer. Især oprindelsesland synes at have en stærk forklaringskraft, men sjældent selvstændigt. Dermed synes oprindelsesland, den religiøse retning og status som flygtning/indvandrer at kunne forklare mest i kombination.

Det viser sig således, at respondenter fra Iran og Ex. Jugoslavien synes at være de mindst religiøse, da disse både opfatter sig som ikke/mindst mulig religiøse, typisk har haft en uforandret eller faldende religiøsitet, gerne mener at religion spiller ingen/lille rolle på den måde, de lever deres liv og ofte viser et lille religiøst engagement. Omvendt synes respondenter fra arabisktalende lande som Irak, Libanon/Palæstina/statsløse ofte at betragte sig som mest mulig religiøse, have en uforandret eller stigende religiøsitet, i højere grad end andre at mene, at religion har stor indflydelse på den måde, de lever deres liv, ligesom de i højere grad end andre udviser et religiøst engagement. I midterkategorien placerer respondenter fra Tyrkiet, Pakistan og Somalia sig. Det er imidlertid også disse tre grupper, der synes at have størst tilknytning til moskeer, da de i højere grad end andre kommer i moskeen og deltager i fredagsbønnen. Resultaterne fra IntegrationsStatus indikerer endvidere, at et flertal af respondenterne er kommet til Danmark som flygtninge, og at flygtninge i mindre grad end indvandrere mener, at religion har indflydelse på den måde, de lever deres liv, ligesom de viser et mindre religiøst engagement. Dette kan forklares med, at nogle kan være flygtet fra et religiøst undertrykkende regime, mens indvandrere kan have en interesse $i$ at opretholde deres tilknytning til religion. Endelig synes sunnimuslimer i højere grad end såvel shiamuslimer som gruppen af muslimer i øvrigt at betragte sig mest mulig religiøse, vise et større religiøst engagement og mene, at religion har indflydelse på den måde, de lever på til daglig. Mens muslimer i øvrigt typisk viser 
mindst religiøst engagement, mener de i højere grad end shia- og sunnimuslimer, at religion har indflydelse på ægteskab og familieliv. Resultaterne er delvist forklaret med henvisning til den nationale oprindelse, delvis med forskelle i den religiøse praksis.

Resultaterne indikerer følgelig, at hvad der sker med førstegenerationsimmigranters religiøsitet i mødet med det danske samfund til dels afhænger af, om man er kommet til Danmark som indvandrer fra et sunnimuslimsk, arabisktalende land eller som flygtning på grund af manglende frihed fra religion i eksempelvis Iran.

\section{Opsamling på undersøgelsesresultater og konklusion}

Denne artikel har haft til formål at forklare, hvad der sker med førstegenerationsimmigranters religiøsitet i mødet med det danske samfund. De kvalitative interviews synes at indikere tre forskellige idealtyper for strategier, som man bevidst eller ubevidst kan søge tilflugt, styrke eller støtte i, når man migrerer til et samfund som det danske. Disse idealtyper kan henholdsvis karakteriseres som 1) adaptionsstrategi: en ubetinget accept og adaption af destinationslandets adfærd, værdier og normer, 2) kombinationsstrategi: en opretholdelse og en beskyttelse af den oprindelige identitet, tradition og kultur samtidig med, at man betragter sig som en fungerende del af det nye samfund og 3) distanceringsstrategi: en afstandtagen fra og disidentifikation med den omgivende majoritet, og af den grund en forstærkelse af den oprindelige identitet, deriblandt den religiøse. Strategierne skal ikke forstås som fastlagte, men som strategier der kan ændres over tid, således at man indledningsvis kan vælge én strategi i sit første møde med det danske samfund, og at denne strategi kan ændres til en anden under opholdet i Danmark.

Det, der synes at være afgørende for, at man vælger én strategi frem for en anden, er faktorer knyttet til såvel oprindelseslandet som destinationslandet. Her forekommer der indikatorer på, at den primære og sekundære socialisering, den religiøse retning og det, om man er rejst fra oprindelseslandet som flygtning eller indvandrer, er af betydning for valg af kognitiv strategi. Således er sandsynligheden for, at man vælger en adaptionsstrategi eller en kombinationsstrategi - og betragter sig som meget lidt religiøs - størst, hvis religion har haft en begrænset rolle i socialiseringsprocessen, hvis man er flygtet fra oprindelseslandet på grund af mangel på frihed fra religion samt, hvis man er shiamuslim eller 
anden muslimsk retning end sunni og dermed slækker på dele af den religiøse praksis. Distanceringsstrategien synes derimod at hænge sammen med en primær og sekundær socialisering, hvor religion har haft en afgørende betydning, oprindelse i et sunnimuslimsk eller et arabisktalende land og det, at man er rejst fra oprindelseslandet som indvandrer eller flygtning af ikke-religiøse årsager. Disse faktorer forekommer at have betydning for, at man betragter sig som mest mulig religiøs.

Den etniske konstellation i boligområdet og omgangskredsen, forholdet til andre etniske grupper i minoritetsgruppen og forholdet til den danske majoritet er faktorer i destinationslandet, der ligeledes er af betydning for valg af kognitiv strategi. Adaptionsstrategien og det at betragte sig som meget lidt religiøs synes at hænge sammen med en stærk tilknytningsfølelse og identifikation med det danske samfund og høj interaktion med danskere i det geografiske område, i det nære boligområde som i den nære omgangskreds. Sammenhængen kan både komme til udtryk ved, at man som meget lidt religiøs søger sådanne boligområder samt bekendtskaber, ligesom sådanne bekendtskaber og boligområder kan tænkes at fremme en svag religiøsitet. Er forholdet til danskere derimod karakteriseret ved svag identifikation, og omgiver man sig primært med personer af udenlandsk oprindelse såvel i boligområdet som i den nære omgangskreds, er det mere sandsynligt, at man betragter sig som mest mulig religiøs og vælger distanceringsstrategien. Også her kan kausaliteten tænkes modsat, således at det netop er fordi, man betragter sig som meget religiøs, at man ikke kan identificere sig med danskere, vælger at bosætte sig i etniske enklaver osv.

Den ubetingede accept og adaption af destinationslandets adfærd, værdier og normer synes ifølge resultaterne fra de kvalitative interviews, at være den strategi, som mange tyr til umiddelbart efter migrationen til Danmark. Denne kan komme til udtryk ved navneforandring, ændring og tilpasning af madvaner, negligering af religiøs praksis og lignende. For så vidt kan man sige, at Danmark umiddelbart kan virke sekulariserende på de etniske minoriteter, når de kommer hertil, idet der fremkommer tendenser til at påbegynde en kritisk vurdering af eget religiøst ståsted. Møder man imidlertid modstand fra den danske majoritet, ofte i forbindelse med at man ikke i majoritetens optik betragtes som en del af gruppen, kan det resultere i en strategiændring, hvor ryggen vendes mod majorite- 
ten og fronten mod de oprindelige kulturelle og religiøse værdier. Hvordan immigranterne bliver mødt af den danske majoritet synes således at kunne være af afgørende betydning for deres videre identifikation med den danske befolkning, og her muligvis også på transformationer i den religiøse selvopfattelse, religionens indflydelse på den måde, man lever sit liv og/eller på det religiøse engagement. Som det ser ud nu, synes de færreste at føle sig som danskere, og resultaterne indikerer en sammenhæng mellem identifikation med danskere og religiøsitet, således at jo mere religiøs man betragter sig, desto mindre dansk føler man sig også - og omvendt.

Mens flertallet ikke føler sig diskrimineret, har vi set, at de der gør, typisk er de mindst religiøse. I de kvalitative interviews forklares dette med danskernes forventning om, at man er religiøs, fordi man har oprindelse i et muslimsk land. Opleves diskrimination af de mest mulig religiøse, er dette typisk i medier og af politikere, primært efter 11. september 2001 og den danske Muhammedkrise.

Undersøgelsens resultater viser, at svaret på, hvad der sker med muslimske førstegenerationsimmigranters religiøsitet i mødet med det danske samfund, er mangesidigt, hvor ikke én faktor, men flere i et dynamisk samspil har betydning for forandringer i den religiøse identitet. Forklaringskraften styrkes således af, at flere faktorer optræder samtidigt. Som eksempel kan det, at man både er af arabisk herkomst, er bosat i et boligområde med et flertal af beboere af udenlandsk baggrund og har en omgangskreds, primært bestående af personer af anden etnisk baggrund end dansk, der deler samme verdensopfattelse og religiøse værdier som én selv, have betydning for en styrkelse af den religiøse identitet. Undersøgelsen har udvidet forståelsesrammen for transformationerne i den religiøse identitet, men skaber samtidig flere ubesvarede spørgsmål. Følgelig synes det afgørende at kunne bestemme, hvilken kausal retning, der er den mest plausible: Er det til eksempel den etniske enklave, der fremmer religiøsiteten hos de muslimske immigranter, eller er forklaringen nærmere, at de mere religiøse - på grund af oplevelsen af diskrimination fra den danske majoritet, fra politikere og i medier - vælger at omgås personer, der deler samme verdensopfattelse og følgelig bosætter sig i etniske enklaver? Det synes endvidere oplagt at undersøge forandringer $\mathrm{i}$ andre aspekter af religiøsiteten end de her udvalgte. Således er det i høj grad ændringer i den religiøse praksis og den religiøse selvopfattelse, 
der er blevet belyst, mens ændringer i selve troen, eksempelvis gudebilledet og efterlivsforestillinger, ændringer i ritualer, religiøse institutioner og religiøs arkitektur ligeledes ville være interessante at tage med i betragtning. Ligeledes bør opfølgende undersøgelser inddrage andre nationaliteter end de i dette studie udvalgte for dermed at tilstræbe en mere repræsentativ undersøgelse. Endelig kan undersøgelsens resultater anvendes til at sætte andengenerationsimmigranters religiøsitet i perspektiv og eventuelt forklare forskellige mønstre heri. Det, at nogle af førstegenerationsimmigranterne midlertidigt bliver mere religiøse i mødet med eller under opholdet i Danmark, kan indikere, at den stigende religiøsitet, der er dokumenteret blandt nogle unge andengenerationsimmigranter ligeledes har karakter af en midlertidig forandring, eventuelt igangsat af en oplevelse af diskrimination fra eller manglende identifikation med den danske majoritet. Denne undersøgelse bør derfor alene betragtes som et fundament for nye undersøgelser, der kan udvide vores horisont $\mathrm{i}$ forhold til hvilke mekanismer der er i spil i det danske samfund, i forholdet mellem de etniske minoriteter og den danske majoritet, i forhold til identifikation og diskrimination, og betydningen heraf for transformationer i den religiøse identitet.

\section{Litteratur}

Berger, P. \& Luckmann, T. 2004: Den sociale konstruktion af virkeligheden. København K. Akademisk Forlag.

Berger, P. 1969: The Sacred Canopy. Elements of a sociological Theory of religion. New York. Anchor Books. Doubleday \& Company, Inc., Garden City.

Jenkins, R. 2006: Social identitet. Århus, Forfatterne og academica.

Johansen, K. L. 2002: Muslimske stemmer. København, Akademisk Forlag.

Kühle, L. 2006: ”Moskeer i Danmark - islam og muslimske bedesteder”. Højbjerg, Forlaget Univers.

Nielsen, H.J. 2004: ”De etniske minoriteter” i Danskernes scerpraeg. København, C forfatterne og Hans Reitzels Forlag.

Nielsen, H. (red.) 2000: Samtaler fremmer forståelse. Den danske Folkekirkes Islamrapport. København, Unitas. 
Ramadan, T. 2002: At vaere europceisk muslim. Højbjerg, Forlaget hovedland.

Riis, O. 2005: Religiøs pluralisme i Norden. (Oplæg til nordisk seminar i Alta, februar 2005) - 34 sider.

Riis, O. 1996: Metoder og teorier i religionssociologien. Århus, Aarhus Universitetsforlag.

Simonsen, J. B. 2006: Hvad er islam. København, Jørgen Bæk Simonsen og Akademisk Forlag A/S.

Smith, C., Sikkink, D. \& Bailey, J. 1998: Devotion in Dixie and beyond: A Test of the "Shibley Thesis" on the Effects of Regional Origin and Migration in Individual Religiosity. Journal for the Scientific Study of Religion, Vol. 37, No. 3, (Sep. 1998), pp. 494-506.

Van Tubergen, F. 2006: Religious Affiliation and Attendance Among Immigrants in Eight Western Countries: Individual and Contextual Effects, in: Journal for the Scientific Study of Religion 2006, 45 (1): 1-22.

Azadeh Afsar er uddannet cand.scient.soc. ved Aalborg Universitet, marts 2007.

\footnotetext{
${ }^{1}$ I IntegrationsStatus 2004 er ikke foretaget en nærmere specificering af, om det at religion eksempelvis ikke har indflydelse på ægteskab og familieliv er ensbetydende med, at religion ikke har betydning i forhold til livets rites-de-passages. Ligeledes afgrænser IntegrationsStatus sig fra andre betydningsfulde aspekter, såsom deltagelse i religiøse ritualer, som kan være meget sigende for det religiøse engagement. Da denne undersøgelse i høj grad læner sig op ad IntegrationsStatus indgår sådanne aspekter følgelig heller ikke i nærværende undersøgelse.

${ }^{2} \alpha$-værdi $0,024, \gamma=-0,106$.

${ }^{3} \alpha$-værdi $0,000, \gamma=0,303$.

${ }^{4} \alpha$-værdi $0,032, \gamma=-0,123$.

${ }^{5} \alpha$-værdi 0,016 .

${ }^{6} \alpha$-værdi 0,001 .
} 